\title{
In Vivo Dose and Duration Dependent Effects of a Dioxin $(2,3,7,8$ TCDD) on Few Lysosomal Enzymes in Mice Brain
}

\author{
Jyoti Jigyasi ${ }^{1}$ and Rahul Kundu ${ }^{2} *$ \\ 1,2 (Department of Biosciences, Saurashtra University, Rajkot-360005, Gujarat State, India)
}

\begin{abstract}
TCDD, a toxic dioxin, has a high rate of biomagnification by accumulating in adipose tissue of living organism. The present study reports that the in vivo exposure of even environmentally available low concentration of TCDD affects the lysosomal enzymes in mice brain cells. The study tested the hypothesis that low concentration of TCDD provokes dose and duration dependent effects to lysosomal enzymes in mice brain cells. Selected groups of animals were administered two very low doses of TCDD $(0.004 \mathrm{mg} / \mathrm{kgbw} / \mathrm{d}, 0.04 \mathrm{mg} / \mathrm{kg}$ bw/d) for 2,4 and 6 days of exposure durations. The results indicated TCDD caused significant exposure duration dependent effects to lysosomal enzymes in mice brain cells. Though it is not very clear at this point, but the results suggested that the observed alterations in the lysosomal enzymatic activity might have affected few metabolic pathways of the cell and disturbed cellular homeostasis by producing intracellular ions and ROS. These changes directly or indirectly affected the cellular metabolic pathways in different degrees depending on the dose and exposure durations of the dioxin and might have evoked apoptotic changes into the cells.
\end{abstract}

Keywords: $T C D D$, dose and duration, lysosomal enzymes, mice, brain

\section{Introduction}

2,3,7,8 TCDD is an environmental pollutant, produced during the improper burning of paper, pulp, wastes ${ }^{[1-3]}$ and tend to accumulate in the adipose tissues of animals including human, exposed through different environmental sources ${ }^{[4,5]}$. Dioxin like PCBs contaminated fish consumed by pregnant women reported developmental disorder and cognitive deficits in infants ${ }^{[6-8]}$. Few studies in Japan and Taiwan reported that dioxin and PCBs exposure from contaminated rice oil caused endocrine disruption, neurobehavioral deficits and psychomotor developmental disorder ${ }^{[9,11]}$. It was reported earlier that high level consumption of PCBs, dioxin and furan is related with high level of pollutants accumulation in breast milk during the lactation period and reduced the neonatal neurological optimity ${ }^{[12]}$. In one of the neurotoxicological studies of dioxin, it was reported that a single dose of TCDD exposure caused reduction of inositol in rat brain cells ${ }^{[13]}$. Similarly, it was observed that the cumulative exposure of TCDD, endrin and chromium induced oxidative stress and tissue damage in rat liver and brain cells ${ }^{[14]}$. It has also been observed that the ovoexposure of 2,3,7,8 TCDD caused brain lesions and evoked several developmental issues in chick embryo, which was possibly a classic case of dose and duration dependent neurotoxicity of TCDD ${ }^{[15]}$. Several studies reported that the chronic exposure of PCBs and TCDD produces oxidative stress by ROS, evokes lipid peroxidation and DNA damage in rat brain tissue ${ }^{[16,17]}$. It was reported earlier that oxidative stress was associated with apoptotic cell death induced by TCDD in human neuronal cell ${ }^{[18]}$. It was reported that TCDD, in in vivo conditions, generally binds with AhR receptor and targets to blood brain efflux transporter which reduces the accumulation of drug therapeutic agents in neuronal cells ${ }^{[19]}$. Therefore, the increased intracellular ions are possibly associated with intracellular signaling alteration due to TCDD toxicity ${ }^{[20]}$. Going through the literature it was observed that studies related to TCDD effects on lysosomal enzyme in brain tissue are rare. Therefore, the present study was undertaken to study the dose and duration dependent effects of low dose TCDD on few lysosomal enzymes in mice brain. The study tested the hypothesis that low concentration of TCDD provokes dose and duration dependent effects to lysosomal enzymes in mice brain cells.

\section{Materials And Methods}

Healthy inbred female Swiss Albino mice, around 3 months of age and weighing $30 \pm 5 \mathrm{~g}$, were used for the entire study. The animals were fed with commercially available rodent diet and water ad libitum, and kept in the animal house facilities under hygienic condition as per CPCSEA India, guidelines. Humidity and temperature were controlled $\left(25 \pm 2^{\circ} \mathrm{C}\right)$ and diurnal cycle of $14: 10 \mathrm{~h}$ was maintained. All experiments were conducted according to norms approved by CPCSEA, India.

The Dioxin, 2,3,7,8 TCDD, in its purest form, was obtained from Sigma Aldrich Chemicals Pvt. Ltd. (CAS No. 1746-01-6). All other chemicals used for this study were of analytical grade and procured from reputed Indian chemical companies. A total of 81 inbred female Swiss albino mice of the same age and weight group were taken for experimental studies. The selection of doses were based on (a) TCDD residues available in 
the environment and possible human exposure through oral route from different environmental sources (b) evaluation of toxicity studies and Minimum Risk Dose (MRD) for extrapolating from animal model to human for TCDD administered through oral route. Groups of mice were administered two different sublethal doses of TCDD $(0.004 \mathrm{mg} / \mathrm{kg} \mathrm{bw} / \mathrm{d}, 0.04 \mathrm{mg} / \mathrm{kg}$ bw/d) for 2,4 and 6 days of exposure durations. The whole brain tissue was pooled from at least three animals for each dose group and suspended in chilled Sucrose- EDTA-Imidazole (SEI) buffer at pH 7.1 to remove excess blood and adhering meninges. Known amount of whole brain tissue was sampled from the pooled tissues of all animals and homogenized in chilled phosphate buffer ( $\mathrm{pH}$ 7.0) to obtain a $10 \%(\mathrm{w} / \mathrm{v})$ homogenate. Enzyme extract preparation for purified lysosomal enzymes was carried out by the method of Beaufay ${ }^{[21]}$. Homogenate was centrifuged at $2000 \mathrm{rpm}$ for $8 \mathrm{~min}$ at $4 \mathrm{C}$. the obtained supernatant was re-suspended in phosphate buffer and centrifuged at $11,000 \mathrm{rpm}$ for $40 \mathrm{~min}$ to get lysosomal fraction. The resultant sediment was re-suspended in phosphate buffer with $0.1 \%$ Triton X 100 to obtain a supernatant of lysosomal fraction. The activity of Acid Phosphatase, $\alpha$-Galactosidase, $\beta$-Glactosidase and $\beta$-Glucuronidase were estimated using this lysosomal fraction. The enzyme assay was done as per the method of Tettamanti and Masserini ${ }^{[22]}$. Protein concentration of the tissue homogenate was estimated by the Lowry et al. ${ }^{[23]}$, using bovine serum albumin as the standard. The obtained data were subjected to various statistical analyses like oneway and two-way nested ANOVA and ' $t$ ' test for their cumulative acceptability and hypotheses testing. All statistical analyses were done as per Sokal and Rohlf ${ }^{[24]}$.

\section{Results and Discussion}

Results of the present study showed drastic changes in the lysosomal enzymatic activity in all the doses and exposure durations. The specific activity of acid phosphatase showed 1.5 fold reduction after the exposure of $0.04 \mathrm{mg} / \mathrm{kg} \mathrm{bw} / \mathrm{d}$ dose of TCDD for 6 days of exposure duration. Whilst, the lower $(0.004 \mathrm{mg} / \mathrm{kg} \mathrm{bw} / \mathrm{d})$ dose of TCDD increases 1 fold of the specific activity after 4 days of exposure duration compare to the control (Fig. 1). Similarly the activity of $\alpha$-galactosidase showed 1 fold reduction after the exposure of $0.004 \mathrm{mg} / \mathrm{kg} \mathrm{bw} / \mathrm{d}$ of TCDD. However, the higher dose group showed 2.5 fold reduced enzymatic activity compare to the control animals, followed to slight stimulation after 4 days of exposure durations (Fig. 1). The specific activity of $\beta$ galactosidase showed slight inhibition after the exposure of lower dose of TCDD in higher exposure durations. Whilst, the higher dose of TCDD causes stimulation after the 6 days of exposure duration (Fig. 1). The specific activity of $\beta$-glucuronidase showed inhibitory trend after the exposure of both doses of TCDD for 6 days of exposure durations (Fig. 1).

PCBs and dioxin like compounds tends to persist into the environment for a long time and through food chain it exposed to the higher consumers including human ${ }^{[25]}$. Dioxin like chlorinated compounds induce oxidative stress by producing intracellular free radicals and $\operatorname{ROS}^{[20]}$. Oxidative stress caused by reactive oxygen species is also speculated to be pathologically important for various neurodegenerative processes and cognitive deficits ${ }^{[26]}$. It was documented in available literature that free radicals, generated by the environmental pollutants, influence gene expressions and prerequisite apoptotic processes ${ }^{[27]}$. The observed results suggested that the disturbances in the activity of lysosomal enzymes might have activated the metabolic pathway thereby disrupted the normal neuronal functions of the brain ${ }^{[28]}$. The results of the two way nested ANOVA showed a very prominent exposure duration dependent effects of TCDD in the brain tissue (Table 1). The maximum significant variation were observed in the activity of acid phosphatase $(98.38, p=0.05)$, however, the $t$-test performed between the control and individual exposure durations within each group showed significant variations in all exposure durations (Table 2). The highest significant variations were observed in the activity of $\beta$-glucuronidase in lower dose of TCDD for 2 days of exposure duration. The results of single Factor ANOVA showed significant variations in each dose group of all selected enzymes (Table 3). Highly significant variation were observed in $\alpha$-galactosidase activity in brain tissue $(64.08, p=0.05)$. TCDD and related compounds are reported to bind with cytoplasmic AhR receptors and known to disrupt the glucuronyl transferase activity by affecting different gene expression ${ }^{[29]}$. Such type of environmental factors are found to be in low concentration in brain whilst these affects to cellular mechanism leading to metabolic pathway ${ }^{[30]}$.

Lysosomal enzymes are important for the cell degradation processes ${ }^{\left[{ }^{11-32]}\right.}$. It has been reported that the formation of autophagic vesicles were related with the alteration in the lysosomal membrane integrity ${ }^{[33]}$. Acid phosphatase affects the metabolic rates of phosphates. Therefore, in this study it can be said that the inhibition of acid phosphatase activity might have reduced the glucose phosphorylation turnover in brain tissue. Presence of $\beta$-glucuronidase has been demonstrated in all vertebrates' animals. It catalyzes hydrolysis of terminal- $\beta$ - (1-6) and $\beta$ - (1-4) glycosidic linkage in carbohydrate chain which helps in trans-glycosylation process ${ }^{[34]}$. Inhibition of $\beta$ - glucuronidase and $\alpha$ - galactosidase were therefore, related with the decrease of metabolic rate of glycosylation by this enzyme in brain tissue ${ }^{[35]}$. The present study thus, indicating that low dose exposure of TCDD caused a clear exposure duration dependent effects to lysosomal enzymes in mice brain tissue. Though it is not very clear at this stage, but TCDD probably produced ROS and free radicals by different cellular reactions like altered lysosomal enzyme activity. These ROS might be responsible for the production of oxidative stress 
and disturbed cell homeostasis. It is also possible that the altered enzymes together with the produced ROS induced cellular signaling which ultimately evoked cellular apoptotic process in the mice brain cells.
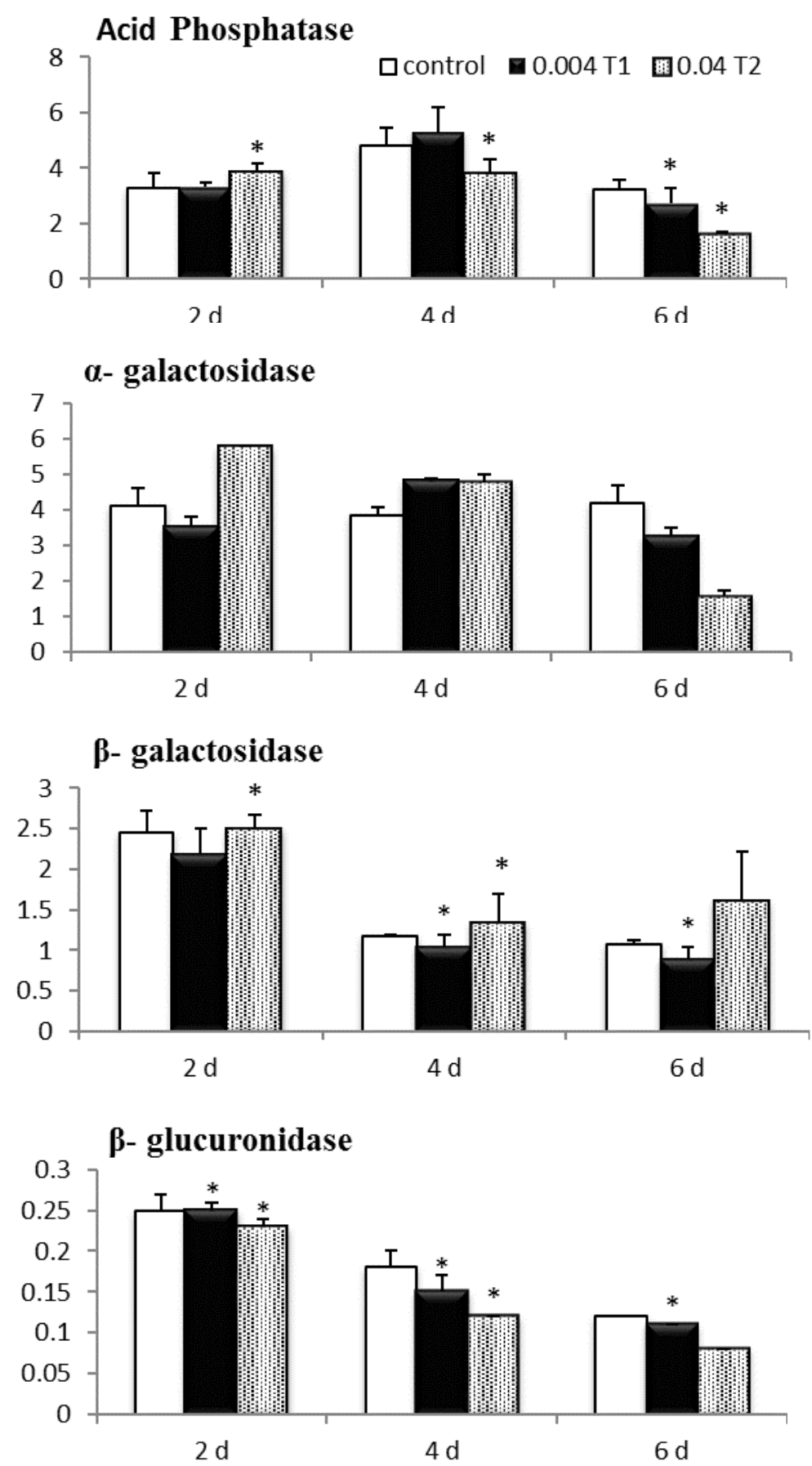

Fig. 1. Histograms showing dose and duration dependent alterations in the specific activity of various lysosomal enzymes after in vivo TCDD intoxication. Error bars represents SD and '*' sign represents the significant variations at $\mathrm{P}=0.05$ level in the specific activity of mice. 
TABLE 1. Results of Two-way nested ANOVA between control and toxicated groups of TCDD exposed mice brain tissue.

\begin{tabular}{ccccc}
\hline & Acid Phosphatase & $\boldsymbol{\alpha}$-Galactosidase & $\boldsymbol{\beta}$-Galactosidase & $\boldsymbol{\beta}$-Glucuronidase \\
\hline Amongst doses & 0.03 & 1.11 & 0.10 & 0.95 \\
Within durations & $98.38^{* *}$ & $16.56^{* *}$ & $19.94^{* *}$ & $54.8^{* *}$ \\
\hline
\end{tabular}

*Significance at $\mathrm{P}=0.05(\mathrm{~F}$ crit of $\mathrm{dF}=3,8)=3.63$

$* *$ Significance at $\mathrm{P}=0.05(\mathrm{~F}$ crit of $\mathrm{dF}=8,35)=2.59$

TABLE 2. Results of ' $t$ ' test between control and individual exposure duration within each dose group in brain tissue of TCDD exposed mice.

\begin{tabular}{|c|c|c|c|c|c|c|c|c|}
\hline & \multicolumn{2}{|c|}{ Acid Phosphatase } & \multicolumn{2}{|c|}{$\alpha$ - Galactosidase } & \multicolumn{2}{|c|}{$\beta$-Galactosidase } & \multicolumn{2}{|c|}{$\beta$-Glucuronidase } \\
\hline & $0.004 \mathrm{mg}$ & $0.04 \mathrm{mg}$ & $0.004 \mathrm{mg}$ & $0.04 \mathrm{mg}$ & $0.004 \mathrm{mg}$ & $0.04 \mathrm{mg}$ & $0.004 \mathrm{mg}$ & $0.04 \mathrm{mg}$ \\
\hline 2 days & 0.48 & $3.65^{*}$ & 1.83 & $22.44^{*}$ & 1.08 & $3.32 *$ & $47.02 *$ & $13.67^{*}$ \\
\hline 4days & 2.55 & $26.03 *$ & $7.40 *$ & $17.29 *$ & $4.43^{*}$ & $9.38 *$ & $3.34 *$ & $8.11 *$ \\
\hline
\end{tabular}

*Significance at $\mathrm{P}=0.05(\mathrm{~F}$ crit $=2.77)$

TABLE-3. Results of Single way ANOVA between individual exposure duration within each dose group.

\begin{tabular}{ccccc}
\hline & Acid Phosphatase & $\boldsymbol{\alpha}$-Galactosidase & \multicolumn{1}{c}{$\boldsymbol{\beta}$-Galactosidase } & \multicolumn{1}{c}{$\boldsymbol{\beta}$-Glucuronidase } \\
\cline { 2 - 5 } Control & 33.73 & 62.43 & 14.83 & 11.90 \\
T1 (0.004) & $32.72^{*}$ & $64.08^{*}$ & $24.84^{*}$ & $36.35^{*}$ \\
T2 (0.04) & $16.50^{*}$ & $30.40^{*}$ & $16.50 *$ & $7.30^{*}$ \\
\hline
\end{tabular}

*Significance at $\mathrm{P}=0.05(\mathrm{~F}$ crit $=5.14)$

\section{Acknowledgements}

Authors are thankful to UGC, Govt. of India, New Delhi for supporting this study through its CAS programme. The senior author is thankful to UGC, New Delhi for a Meritorious Fellowship.

\section{References}

[1]. Schwetz BA, Norris JM, Sparschu GL, Rowe VK, Gehring PJ, Emerson JL and Gerbig CG, Toxicity of chlorinated dibenzo-pdioxin, Environmental Health Perspectives 5, 1973,87-99.

[2]. Beatty PW, Vaughn WK and Neal RA, Effect of alteration of rat hepatic mixed function (MFO) activity on the toxicity of 2,3,7,8 tetra chloro di benzo-p-dioxin (TCDD). Toxicology and Applied Pharmacology, 45, 1978, 513-519.

[3]. Olson JR, Holscher MH and Neal RA, Toxicity of 2,3,7,8 tetra chloro di benzo-p-dioxinin the Golden Syrian hamster, Toxicology and Applied Pharmacology, 55, 1980, 66-78

[4]. Jigyasi J and Kundu R, Low dose TCDD affects membrane bound ion dependent ATPases in mice liver. IOSR Journal of Environmental Science, Toxicology and Food Technology, 2, 2013a, 15-19.

[5]. Pathak S and Kundu R, Effects of low concentration of a polychlorinated biphenyls, arochlor 1254 on membrane bound ion dependent ATPases in mice liver, Indian Journal of Experimental Biology 51(6), 2013b,477-80

[6]. Fein GG, Jacobson JL, Jacobson SW, Schwartz PM and Dowler JK, Prenatal exposure to polychlorinated biphenyles: effect on birth size and gestational age, Journal of Pediatrics, 105, 1984, 315-320

[7]. Jacobson SW, Fein GG, Jacobson SW, Schwartz PM and Dowler JK, The effect of intrauterine PCBs exposure on visual recognition memory, Child Development, 56, 1985, 853-860.

[8]. Jacobson JL and Jacobson SW, Intellectual impairment in children exposed to polychlorinated biphenyls in utero. The New England Journal of Medicine, 335, 1996, 783-789.

[9]. Harada M, Intrauterine poisoning: Clinical and epidemiological studies and significance of the problem. Bulletin of the Institute of Constitutional Medicine, Kumamato University, 25(suppl) 1976.

[10]. Wong KC and Huang MY, Children born to PCB poisoned mothers, Clinical Medicine Journal (Taipei) 7, 1981, 83-87

[11]. Hsu ST, Ma CI, Hsu SK, Wu SS, Hsu NHM, Yeh CC and Wu SB, Discovery and 16 epidemiology of PCB poisoning in Taiwan: A four year follow-up, Environmental Health Perspectives, 59, 1985, 5- 10.

[12]. Huisman M, Koopman-Esseboom C, Fidler V, Hadders-Algra M, van der Paauw CG, Tuinstra LG, Weisglas-Kuperus N, Sauer PJ, Touwen BC and Boersma ER, Perinatal exposure to polychlorinated biphenyls and dioxins and its effect on neonatal neurological development. Early Human Development 41, 1995a, 111-127.

[13]. Pohjanvirta, R., Hirvonen, M. R., Unkila, M., Savolainen, K., and Tuomisto, J, TCDD decreases brain inositol concentrations in the rat, Toxicology Letters, 70, 1994, 363-372.

[14]. Bagchi D, Balmoori J, Bagchi M, Ye X, Williams CB and Stohs SJ, Comparative effects of TCDD, endrin, naphthalene and chromium (VI) on oxidative stress and tissue damage in the liver and brain tissues of mice. Toxicology 175, 2002, 73-82.

[15]. Henschel KP, Wenzel A, Diedrich M and Fliedner A, Environmental hazard assessment of pharmaceuticals, Regulatory Toxicology and Pharmacology, 25(3), 220-225.

[16]. Hassoun EA, Li F, Abushaban A and Stohs S, The relative abilities of TCDD-induced oxidative stress in the hepatic and brain tissues of rats after subchronic exposure, Toxicology, 145, 2000, 103-113. 
[17]. Hassoun EA, Wang H, abushaban A and Stohs SJ, Induction of oxidative stress in the tissues of rats after chronic exposure to TCDD, 2,3,4,7,8 pentachlorodibenzo furans and 3,3',4,4',5 pentachloro biphenyls, Journal of Toxicology and Environmental Health A, 65, $2002,825-842$.

[18]. Lee JY, Kim JW, Cho SD, Kim YH, Choi KJ, Joo WH, Cho Yk and Moon JY, Protective role of ginseng extract against apoptotic cell death induced by 2,2',5,5' tetrachloro biphenyls in neuronal SK-N-MC cells, Life. Science, 75, 2004, $1621-1634$.

[19]. Wang X, Sykes DB and Miller DS, Constitutive androstane receptor -mediated upregulation of ATP-driven xenobiotic efflux transporters at the blood-brain barrier, Molecular Pharmacology, 78, 2010, 376-383.

[20]. Pathak S and Kundu R, Low concentration of Aroclor 1254 affects membrane bound ion dependent ATPases in mice kidney, Bioscan, 8(1), 2013c, 1-10

[21]. Beaufay H, Methods for the isolation of lysosomes. In: J.T. Dingle, ed. Lysosomes: A Laboratory Handbook North-Holland Publ Co Amsterdam 1972.

[22]. Tettamanti G and Masserini M, Beta mannosidase. In: methods of enzymatic analysis III eds edited by Bergmeyer H.U. Verlag Chemie, Weinheim, Deerfield beach, Florida, Basel 1984.

[23]. Lowry OH, Rosebrough NJ, Farr AL and Randall RJ, Protein measurement with the folin phenol reagent, Journal of Biological Chemisry, 193, 1951, 265-275

[24]. Sokal RR and Rohlf FJ, Biometry, W.H. Freeman and Company. San Francisco, 1969, 260

[25]. Agency for toxic substances and disease registry (ATSDR), Toxicological profile for aluminum. US Dept of Health \& Human Services. Atlanta, GA, 2000.

[26]. Gray SL, Hanlon JT, Landerman LR, Artz M, Schmader KE and Fillenbaum GG, Is antioxidant use protective of cognitive function in the community-dwelling elderly? The American Journal of Geo Pharmacotherapy, 1, 2003, 3-8

[27]. Gonthier B, Signorini-Allibe N, Soubeyran A, Eysseric H, Lamarche F and Barret L, Ethanol can modify the effects of certain free radical-generating systems on astrocytes, Alcoholism Clinical and Experimental Research 28(4),2004, 526-34.

[28]. Pathak S and Kundu R, Short-term PCB (Aroclor 1254) toxicity on few phosphatases in mice brain, Dose Response 11(1), 2013a, 1-8

[29]. Vickers AEM, Fischer V, Connors MS, Biggi WA, Heitz F, Baldeck JP and Brendel K, Biotransformation of the antiemetic 5$\mathrm{HT}_{3}$ antagonist tropisetron in liver and kidney slices of human, rat and dog with a comparison to in vivo. European Journal of Drug Metabolism and Pharmacokinetics, 21, 1996, 43-50.

[30]. Tilson HA and PRS Kodavanti, Neurochemical effects of polychlorinated biphenyls: an overview and identification of research needs. Neurotoxicology, 18, 1997, 727-744.

[31]. Beaujouin M and Liaudet-Coopman E, Cathepsin D overexpressed by cancer cells can enhance apoptosis- dependent chemo sensitivity independently of its catalytic activity. Advances in Experimental Biology 617, 2008, 453-461.

[32]. Minazaki Ck, Gagioti S, Zago D, Terra W, Araujo VC and Oliviera RA, Amid phosphatase and cathepsin D are active expressed enzymes in the placenta of cat. Research in vaterinary Science 84, 2008, 326-334.

[33]. De Duve C and Wattiaux R, Functions of lysosomes, Physiological Reviews, 28, 1996, 435-437.

[34]. Hays WS, Wheeler DE, Eghtesad B, Glew RH and Johnston DE, Expression of cytosolic $\beta$-glucosidase in guinea pig liver cells. Hepatology, 28, 1998, 156-163.

[35]. Schimizu K, Shiratori K, Hayashi N, Fujiwara T and Horokoshi H, Effect of troglitazone on exocrine pancreas in rats with streptozotocin - induced diabetes mellitus. Pancreas, 21, 2000, 421-426. 